\title{
Induction of Catalase Activity in a Methanol-utilizing Yeast, Kloeckera sp. No. 2201
}

\author{
Shigeki Yasuhara, Susumu Kawamoro, Atsuo Tanaka, \\ Masako Osumi* and Saburo FukuI \\ Laboratory of Industrial Biochemistry, Department of Industrial Chemistry, \\ Faculty of Engineering, Kyoto University, Kyoto \\ *Department of Biology, Japan Women's University, Tokyo
}

Received March 22, 1976

\begin{abstract}
The methanol-grown cells of Kloeckera sp. No. 2201 exhibit a markedly high catalase activity as compared with the glucose-grown and ethanol-grown cells. In this connection, specific organelles ("microbodies") appear only in the methanol-grown cells. When the yeast cells harvested from a methanol medium (cells whose catalase activity had been enhanced to an appreciable extent: "partially induced cells") were transferred into media containing glucose, ethanol or methanol as the sole carbon and energy source, further increase of catalase activity was mediated only by methanol. This induction of catalase activity was partially inhibited by cycloheximide at its high concentration, but chloramphenicol did not show any effect. Glucose inhibited strongly the induction by methanol, while galactose gave no effect. Electron microscopical observation revealed that the development of microbodies in the cells growing on methanol was hardly affected by cycloheximide. Disappearance of microbodies was observed electron microscopically after the methanol-grown cells (partially induced cells) were transferred to a methanol-glucose medium and cultivated for $8 \mathrm{hr}$. $3^{\prime}, 5^{\prime}$ Cyclic AMP or dibutyryl- $3^{\prime}, 5^{\prime}$-cyclic AMP could not eliminate the inhibitory effect of glucose on the catalase induction. Addition of caffeine or theophylline did not promote the action of the cyclic nucleotides. 3-Amino-1,2,4-triazole inhibited only $40 \%$ of the hydrogen peroxide-decomposing activity in the cell homogenate of methanol-grown cells even at its concentration of as high as $10 \mathrm{~mm}$, while sodium azide inhibited the enzyme activity completely at the concentration of $1 \mathrm{~mm}$.
\end{abstract}

The significance of catalase in methanol oxidation system in yeasts has been demonstrated by several research groups.. ${ }^{1 \sim 4}$ That is, catalase participates in the decomposition of hydrogen peroxide, which is formed in the initial oxidation step of methanol catalyzed by an FAD-dependent alcohol oxidase. Nascent oxygen produced by the catalase reaction serves as oxidizing agent for another molecule of methanol. The relationship between the high catalase activity and appearance of specific organelles ("microbodies") in various kinds of methanol-oxidizing yeasts have been reported. ${ }^{(\sim 7)}$

We have demonstrated first the localization of catalase in the microbodies of different kinds of methanol-grown yeasts by means of cytochemical technique ${ }^{5>}$ together with the isolation of intact microbodies from methanol- grown cells of Kloeckera sp. No. 2201. The isolated microbodies contained catalase, FADdependent alcohol oxidase and D-amino acid oxidase. $^{83}$

The inducibility of catalase as well as other enzymes involved in the yeast methanol oxidation system has been mentioned by Kato et $a .^{3)}$ and Roggenkamp et al. ${ }^{9)}$ However, little has been investigated on the details of catalase induction by methanol. In a previous paper, ${ }^{10)}$ we reported that glucose inhibited the catalase induction by hydrocarbons in Candida tropicalis.

This paper deals with the induction of catalase by methanol in the cells of Kloeckera sp. No. 2201 and the influence of various effectors on the induction. Several properties of the crude catalase from the yeast is also described. 


\section{MATERIALS AND METHODS}

Cultivation of the yeast. The yeast used in this study was Kloeckera sp. No. 2201,11) which was supplied by Prof. K. Ogata, Department of Agricultural Chemistry, Faculty of Agriculture, Kyoto University. The organism was cultivated in the same manner as described in the previous paper. ${ }^{5)}$ The carbon source used was $1 \%(\mathrm{w} / \mathrm{v})$ glucose, $2 \%(\mathrm{v} / \mathrm{v})$ methanol or $2 \%$ (v/v) ethanol.

Preparation of partially induced cells. The yeast cells precultured in a glucose medium for $24 \mathrm{hr}$ were transferred into a methanol medium and cultivated with shaking $(220 \mathrm{rpm})$ for $4 \mathrm{hr}$ at $30^{\circ} \mathrm{C}$. The partially induced cells thus obtained were transferred again into media containing different carbon sources and cultivated for further $8 \mathrm{hr}$. Protoplasts of the cells were prepared as described previously. ${ }^{8,12}$ )

Enzyme assay. The cells were harvested by centrifugation, washed twice with distilled water, and suspended into $0.05 \mathrm{M}$ potassium phosphate buffer, $\mathrm{pH}$ 7.2 , to give the cell concentration of $2 \mathrm{mg}$ dry weight per $\mathrm{ml}$. The cell suspension thus obtained was sonicated for $5 \mathrm{~min}$ at 20 kilocycles per sec below $4^{\circ} \mathrm{C}$. The sonicated cell suspension (cell homogenate) was employed as enzyme source. Catalase activity was assayed spectrophotometrically at $30^{\circ} \mathrm{C}$ by the decrease in the absorbance at $240 \mathrm{~nm}^{97}$ as described previously. ${ }^{\text {) }}$ The reaction mixture was consisted of $1.7 \mathrm{ml}$ of $0.05 \mathrm{M}$ potassium phosphate buffer, pH 7.2, $1.2 \mathrm{ml}$ of $100 \mathrm{~mm}$ hydrogen peroxide in the buffer solution and $0.1 \mathrm{ml}$ of the enzyme preparation (about $10 \mu \mathrm{g}$ protein). Protein was assayed by the method of Lowry et al. ${ }^{13)}$

Electron microscopy. Cells were fixed with glutaraldehyde and post-fixed with potassium permanganate. The details of procedure employed were the same as those described in the previous paper. ${ }^{5}$

\section{RESULTS}

1. Some properties of Kloeckera sp. No. 2201 catalase

1-1. $\mathrm{pH}$ - and temperature-dependency of catalase activity. As shown in Figs. 1 and 2, the optimal $\mathrm{pH}$ and temperature for the catalase of methanol-grown Kloeckera sp. were rather broad so far as the cell homogenate was used as the enzyme source. Thus, we used $\mathrm{pH} 7.2$ and $30^{\circ} \mathrm{C}$ in the subsequent experiments.

1-2. Km value of catalase for hydrogen peroxide. The apparent $K m$ values for

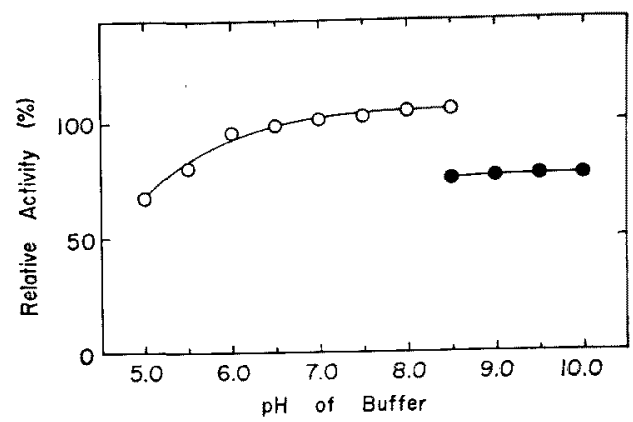

FIG. 1. pH Dependency of Catalase Activity.

Cell homogenate was obtained from the cells grown on methanol for $16 \mathrm{hr}$. The enzyme activity measured at pH 7.2 was expressed as $100 \%$.

$\mathrm{O}-\mathrm{O}$, potassium phosphate buffer; - - , borate buffer.

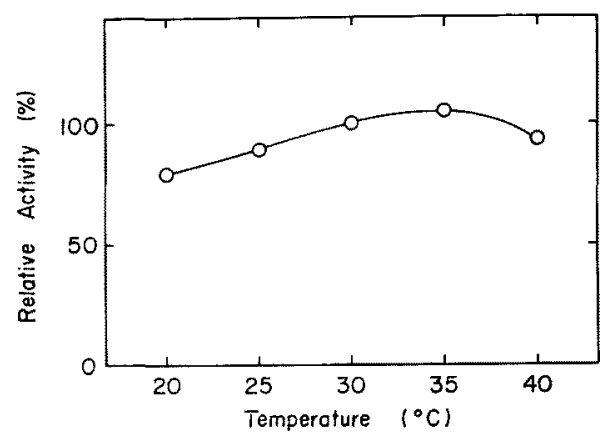

FIG. 2. Temperature Dependency of Catalase Activity.

Cell homogenate was obtained from the cells grown on methanol for $16 \mathrm{hr}$. The enzyme activity measured at $30^{\circ} \mathrm{C}$ was expressed as $100 \%$.

hydrogen peroxide of the catalases in the cell homogenates of methanol-, glucose- and ethanol-grown cells of Kloeckera sp. were calculated as approximately $60 \mathrm{~mm}$, respectively. Because the $K m$ value of beef liver catalase is known to be too high to be determined accurately, the activity in the preparation is usually assayed with the substrate concentration below the $K m$ value. ${ }^{14,15)}$ Hence, in the case of the catalase from Kloeckera sp. No. 2201 having the $K m$ value of about $60 \mathrm{mM}$ for hydrogen peroxide, we used $40 \mathrm{mM}$ of hydrogen peroxide as the substrate in the subsequent experiments, because of the difficulty in spectrophotometric assay of such a high concentration of the substrate. Thus, the enzyme activity in this study should be defined as the activity measured under the 
conditions described in MATERIALS AND METHODS. In a previous paper, ${ }^{16)}$ we reported a low $\mathrm{Km}$ value of the Candida tropicalis catalase for hydrogen peroxide. However, it was proved that the enzyme also showed a low affinity toward hydrogen peroxide when measured spectrophotometrically.

1-3. Effects of inhibitors on catalase activity. As shown in Table I, 3-amino-1,2,4-triazole (AT), an inhibitor of catalase, ${ }^{17)}$ inhibited only $15 \%$ of the catalase activity of methanolgrown Kloeckera sp. at the concentration of $1 \mathrm{~mm}$ and only $40 \%$ even at $10 \mathrm{~mm}$, when the cell homogenate was used as the enzyme source. Similar results were obtained when the cell homogenate was preincubated with the inhibitor prior to the enzymatic reaction. On the other hand, sodium azide inhibited completely the activity at the concentration of $1 \mathrm{~mm}$. The low sensitivity of the enzyme to AT has been demonstrated in other yeasts, ${ }^{16,28\}}$ although the reason is not clear.

\section{TABLE I. EFFECTS OF INHIBITORS ON}

\section{Catalase Activity}

The cell homogenate was obtained from the cells grown in the methanol medium for $16 \mathrm{hr}$. Phosphate buffer, hydrogen peroxide and the inhibitor were mixed and preincubated for $2 \mathrm{~min}$ at $30^{\circ} \mathrm{C}$. The reaction was started by the addition of the cell homogenate.

\begin{tabular}{lcc}
\hline Inhibitor & $\begin{array}{c}\text { Concentration } \\
(\mathrm{mm})\end{array}$ & $\begin{array}{c}\text { Residual } \\
\text { activity } \\
(\%)\end{array}$ \\
\hline None & - & 100 \\
3-Amino-1,2,4- & 1 & 86 \\
triazole & 2 & 81 \\
& 5 & 73 \\
Sodium azide & 10 & 59 \\
& 1 & 0 \\
\hline
\end{tabular}

2. Time-course change in catalase activity of the yeast grown on various carbon source

When Kloeckera sp. No. 2201 cells precultured on glucose were inoculated into the methanol, ethanol or glucose medium and cultivated with shaking, the catalase activity of the cells growing on methanol increased remarkably, reached the maximum at the early to middle exponential growth phase, and decreased gradually thereafter (Fig. 3). On the other hand, the enzyme activity of the cells growing on glucose and on ethanol was maintained at markedly low levels throughout the cultivation period as compared with that of the cells growing on methanol (Fig. 3).

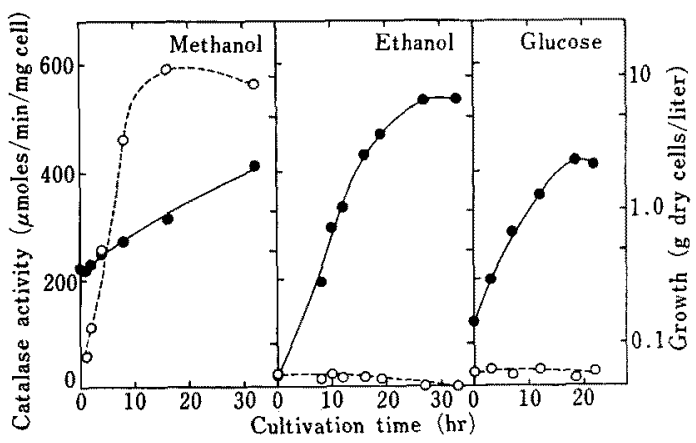

FIG. 3. Time-course Change in Catalase Activity of the Cells Growing on Various Carbon Source

The inoculum was prepared in the glucose medium. The yeast was cultivated in $2 \%$ methanol, $2 \%$ ethanol or $1 \%$ glucose medium.

$\mathrm{O}--\mathrm{O}$, catalase activity; $-\mathbf{0}$, growth.

\section{Induction of catalase activity by' methanol}

The partially induced cells (cultivated for $4 \mathrm{hr}$ in the methanol medium) were transferred into the media containing methanol, ethanol or glucose as the sole carbon source and further cultivated for $8 \mathrm{hr}$. As shown in Fig. 4,

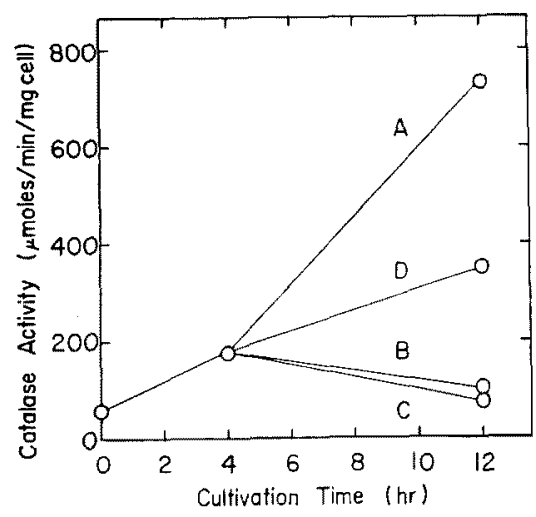

FIG. 4. Effects of Carbon Sources on Catalase Induction.

Partially induced cells (cultivated on methanol for $4 \mathrm{hr}$ ) were transferred into the medium containing $2 \%$ methanol (A), 2\% ethanol (B), $1 \%$ glucose (C) or no carbon source (D), and cultivated for further $8 \mathrm{hr}$ with shaking at $30^{\circ} \mathrm{C}$. 
the catalase activity was strongly induced by methanol (A), while the activities were not enhanced but rather decreased in the cells cultivated with ethanol (B) and glucose (C). When the cells were incubated without any carbon source, the activity increased slightly (D), probably due to the effect of endogenous methanol accumulated during the partial induction phase.

\section{Effect of glucose on catalase induction by methanol}

The partially induced cells were transferred into the methanol media containing various concentrations of glucose or $5 \%$ of galactose, and cultivated for 4 or $8 \mathrm{hr}$ with shaking. As shown in Fig. 5, the presence of glucose in-

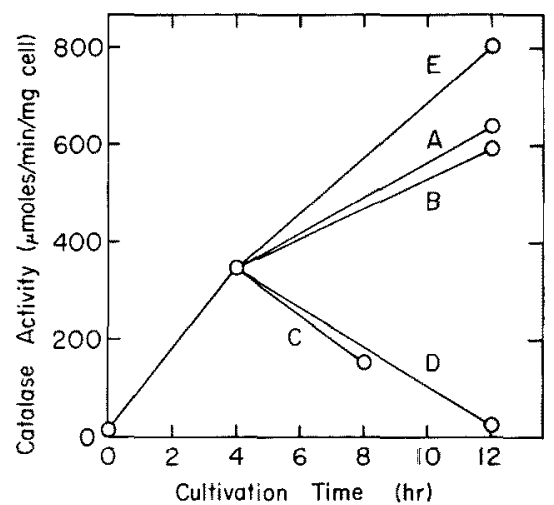

Fig. 5. Effects of Glucose and Galactose on Catalase Induction by Methanol.

Partially induced cells (cultivated on methanol for $4 \mathrm{hr}$ ) were transferred into the methanol medium containing no additive (A), $0.1 \%$ glucose (B), $0.5 \%$ glucose (C), $5 \%$ glucose (D) or $5 \%$ galactose (E), and cultivated for further $4 \mathrm{hr}$ or $8 \mathrm{hr}$ with shaking at $30^{\circ} \mathrm{C}$.

hibited completely the induction of catalase activity by methanol at the concentration of $0.5 \%$ (C) and $5 \%(\mathrm{D})$, but not at the concentration of $0.1 \%$ (B). Galactose, which did not serve as the growth substrate, up to a much higher concentration such as $5 \%$, did not exhibit any inhibitory effect (E). Fig. 6 shows the time-course change in the catalase activity. Glucose-grown cells were incubated in the methanol medium for $4 \mathrm{hr}$, and the partially induced cells thus obtained were transferred into the methanol medium containing $5 \%$ of glucose. After the transfer, the activity in $\mathrm{mg}$ cell still continued to increase for a while, and then decreased gradually to reach a low level. In the meantime, the activity in $\mathrm{ml}$ broth was maintained at the maximum level for several hours, as seen in Fig. 6.

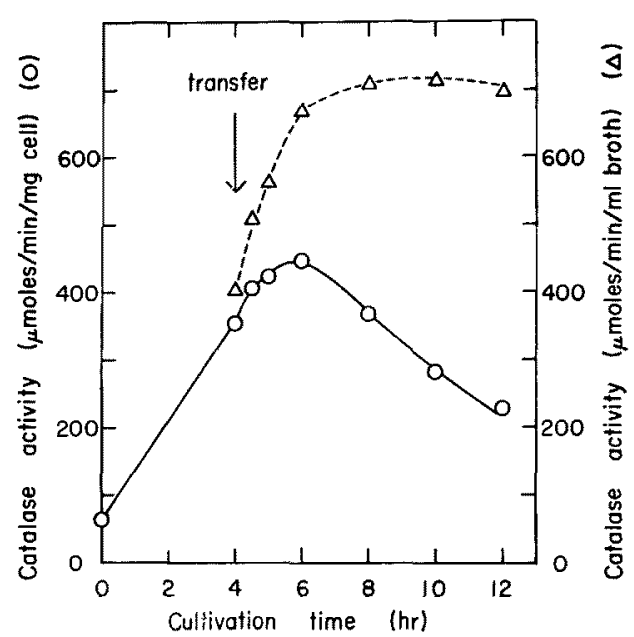

FIG. 6. Effect of Glucose on Catalase Induction by Methanol.

Glucose-grown cells were cultivated on methanol for $4 \mathrm{hr}$, transferred into the methanol medium containing 5\% glucose (arrow), and cultivated with shaking at $30^{\circ} \mathrm{C}$.

$\bigcirc-0$, activity in mg dry cell; $\triangle--\triangle$, activity in $\mathrm{ml}$ broth.

This initial increase may be due to endogenous methanol accumulated during the partial induction period. These results suggest that the induction of the catalase activity by methanol in this yeast is very susceptible to socalled glucose effect, and that the decrease of the enzyme level in the methanol-glucose medium may not be resulted from the inactivation of the enzyme but rather from the inhibition of the enzyme synthesis since the activity in the cells decreases gradually but the total activity did not decreased (Fig. 6).

\section{Effects of cyclic AMP and dibutyryl cyclic AMP against glucose effect}

The partially induced cells were cultivated in the methanol-glucose media supplemented 
with $1 \mathrm{mM}$ cyclic AMP, $0.1 \mathrm{~mm}$ dibutyryl cyclic AMP, $1 \mathrm{~mm}$ cyclic AMP plus caffeine $(200 \mu \mathrm{g} / \mathrm{ml})$, and $0.1 \mathrm{~mm}$ dibutyryl cyclic AMP plus theophylline $(10 \mu \mathrm{g} / \mathrm{ml})$, respectively. Caffeine and theophylline are known to inhibit phosphodiesterase activity in bacteria ${ }^{19)}$ and animal. ${ }^{20)}$ The effect of glucose on the catalase induction, however, was not affected by these drugs at all under the conditions employed (Table II). The effects of cyclic nucleotides were also tested using the protoplasts prepared from the partially induced cells. Even though the induction of catalase activity by methanol was observed clearly in the protoplasts, release of the glucose effect by the nucleotides was not demonstrated, at least under our experimental conditions (See, Table II).

Table II. EfFect of Cyclic AMP on Glucose INHIBITION OF CATALASE INDUCTION

\begin{tabular}{|c|c|c|c|}
\hline Cell & $\begin{array}{c}\text { Glucose } \\
(5 \%)\end{array}$ & Addition & $\begin{array}{c}\text { Relative } \\
\text { catalase } \\
\text { activity } \\
(\%)\end{array}$ \\
\hline \multirow[t]{3}{*}{ Intact $\left.{ }^{a}\right)$} & - & None & 330 \\
\hline & + & None & 36 \\
\hline & + & Cyclic AMP (1 mM) & 31 \\
\hline \multirow[t]{4}{*}{ Intact $\left.{ }^{a}\right)$} & - & None & 242 \\
\hline & + & None & 78 \\
\hline & + & $\begin{array}{l}\text { Cyclic AMP }(1 \mathrm{~mm})+ \\
\text { caffeine }(200 \mu \mathrm{g} / \mathrm{ml})\end{array}$ & 81 \\
\hline & + & $\begin{array}{l}\text { Dibutyryl cyclic AMP } \\
(0.1 \mathrm{mM})+\text { theophyl- } \\
\text { line }(10 \mu \mathrm{g} / \mathrm{ml})\end{array}$ & $P$ \\
\hline \multirow[t]{4}{*}{ Protoplast $\left.^{b}\right\rangle$} & - & None & 468 \\
\hline & + & None & 155 \\
\hline & + & Cyclic AMP (1 mM) & 118 \\
\hline & + & $\begin{array}{l}\text { Dibutyryl cyclic } \\
\text { AMP }(0.1 \mathrm{~mm})\end{array}$ & 138 \\
\hline
\end{tabular}

a) Partially induced cells (cultivated on $2 \%$ methanol for $4 \mathrm{hr}$ ) were incubated for further $8 \mathrm{hr}$ in the $2 \%$ methanol media with or without glucose and various additions.

b) Protoplasts of partially induced cells were incubated for further $8 \mathrm{hr}$ as described above.

c) Catalase activity of partially induced cells or that of protoplasts was expressed as $100 \%$.

6. Effect of antibiotics on catalase induction by methanol

The partially induced cells were further cultivated for $8 \mathrm{hr}$ in the methanol medium supplemented with cycloheximide, chloramph- enicol, or both antibiotics. Cycloheximide, an inhibitor of cytoplasmic protein synthesis, when used at a high concentration such as $2 \mathrm{mg} / \mathrm{ml}$, inhibited slightly the induction of catalase activity by methanol. On the other hand, chloramphenicol, an inhibitor of mitochondrial protein synthesis, did not show any inhibitory effect on catalase induction (Fig. 7).

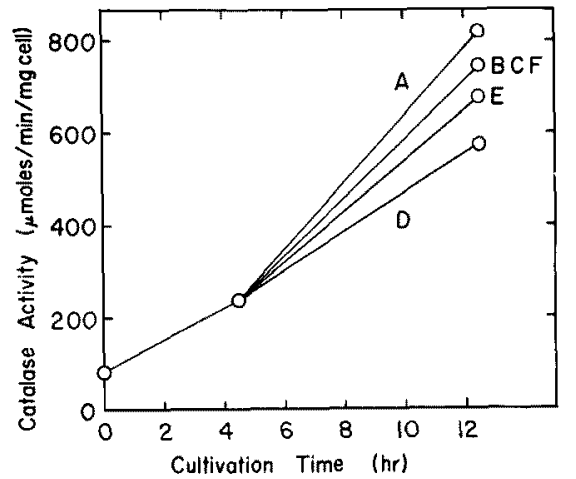

FIG. 7. Effects of Antibiotics on Catalase Induction by Methanol.

Partially induced cells (cultivated on methanol for $4 \mathrm{hr}$ ) were transferred into the methanol medium containing no antibiotic (A), $1 \mu \mathrm{g} / \mathrm{ml}$ of cycloheximide (CHI) (B), $10 \mu \mathrm{g} / \mathrm{ml}$ of $\mathrm{CHI}$ (C), $2 \mathrm{mg} / \mathrm{ml}$ of CHI (D), $2 \mathrm{mg} / \mathrm{ml}$ of chloramphenicol (CAP) (E) or $1 \mu \mathrm{g} / \mathrm{ml}$ of $\mathrm{CHI}$ and $2 \mathrm{mg} / \mathrm{ml}$ of CAP (F), and cultivated for further $8 \mathrm{hr}$ with shaking at $30^{\circ} \mathrm{C}$.

\section{Electron microscopical observation}

As shown in Fig. 8, the partially induced cells (cultivated for $4 \mathrm{hr}$ on methanol) of Kloeckera sp. No. 2201 contained several microbodies of small sizes. When the cells were transferred into the methanol medium and cultivated for further $8 \mathrm{hr}$, well-developed large microbodies were observed clearly in the cells (Fig. 9). The development of microbodies was not observed in the cells incubated for $8 \mathrm{hr}$ without any carbon source (Fig. (Fig. 12). The size of microbodies was almost similar to that in the partially induced cells (See, Fig. 8). On the contrary, microbodies were rarely detected when the partially induced cells were cultivated on methanol-glucose for 8 hr (Fig. 10). Cycloheximide had little effect on the development of microbodies in the cells growing on methanol (Fig. 11). The electron microscopical observation on the development 
of microbodies coincided well with the results of the catalase induction shown in Figs. 4, 5 and 7.

\section{DISCUSSION}

It is of considerable interest from both practical and theoretical viewpoints to study the induction of catalase by methanol in connection to the specific features in ultrastructure of methanol-utilizing yeast cells. When these yeasts were cultivated on methanol, profuse appearance of microbodies was observed. $^{5 \sim 7)}$ This type of organelle, however, was rarely detected in the cells grown on glucose or ethanol. ${ }^{5}$ Furthermore, the catalase activity of the methanol-grown cells of different kinds of yeasts was much higher than that of the corresponding ethanol-grown cells and of glucose-grown cells. The activity was induced strongly by methanol but not by glucose or ethanol. Occurrence of catalase in yeast microbodies has been demonstrated in Saccharomyces cerevisiae by Hoffmann et $a l^{21)}$ and Parish, ${ }^{22}$ and in hydrocarbongrown Candida by us $^{16,23)}$ as well as in methanol-grown yeasts. ${ }^{8,24,25 ;}$ We have found that the development of microbodies during hydrocarbon assimilation by yeast is associated with the marked increase of catalase activity. ${ }^{10,26)}$ Similar phenomena were also observed in the case of methanol-utilizing yeasts. ${ }^{27)}$

Catalase and alcohol oxidase, the enzymes participating in the initial methanol oxidation step, were demonstrated to localize in the microbodies, while formaldehyde dehydrogenase and formate dehydrogenase, the enzymes in the later steps of methanol oxidation, were found exclusively in the cytoplasm. ${ }^{8,24}$ The affinity of the Kloeckera catalase to hydrogen peroxide is very low compared with that of baker's yeast. ${ }^{28}$ However, this low affinity would be compensated by the fact that both of hydrogen peroxide-generating system (alcohol oxidase, etc.) and hydrogen peroxidedecomposing system (catalase) are well organized in microbody. Furthermore, we have revealed cytochemically that catalase is exclusively localized in crystalloid of microbody. ${ }^{3,8}$ ? In the meantime, Sahm et al. ${ }^{7)}$ demonstrated the occurrence of alcohol oxidase in the crystalloid using an oxidase-less mutant of Candida boidinii. These two results strongly suggest that evolution and decomposition of hydrogen peroxide can be efficiently mediated by synergetic action of alcohol oxidase and catalase organized in the crystalloids of microbodies in methanol-utilizing yeasts.

The induction of catalase by methanol was susceptible to the glucose effect. Cyclic nucleotides did not eliminate the effect so far as examined. A higher concentration of the nucleotides than that examined might be needed to release the glucose effect, since Dellweg et $a l^{29)}$ reported the relatively high content of cyclic AMP in methanol-grown Kloeckera sp. No. 2201. The catalase synthesis induced by methanol seemed to be cytoplasmic one, although the protein synthesis was far less sensitive to the inhibitor, cycloheximide, than that of $C$. tropicalis induced by hydrocarbons. ${ }^{10)}$ A similar low effect of cycloheximide toward catalase synthesis was also reported in methanol-utilizing C. boidinii." When the partially induced

FIG. 8. Electron Micrograph of Partially Induced Cell.

Cell was cultivated for $4 \mathrm{hr}$ in $2 \%$ methanol medium. $\mathrm{Mb}$, microbody; $\mathrm{M}$, mitochondrion; $\mathrm{V}$, vacuole. Bar, $0.5 \mu \mathrm{m}$.

FIG. 9. Electron Micrograph of Methanol-grown Cell.

Partially induced cell (cultivated on methanol for $4 \mathrm{hr}$ ) was cultivated for further $8 \mathrm{hr}$ in $2 \%$ methanol medium. $\mathrm{Mb}$, microbody; $\mathrm{M}$, mitochondrion; $\mathrm{N}$, nucleus. Bar, $0.5 \mu \mathrm{m}$.

FrG. 10. Electron Micrograph of Cell Grown on Methanol plus Glucose.

Partially induced cell was cultivated for further $8 \mathrm{hr}$ in $2 \%$ methanol $+5 \%$ glucose medium. $M$, mitochondrion; $N$, nucleus; $V$, vacuole. Bar, $0.5 \mu \mathrm{m}$. 


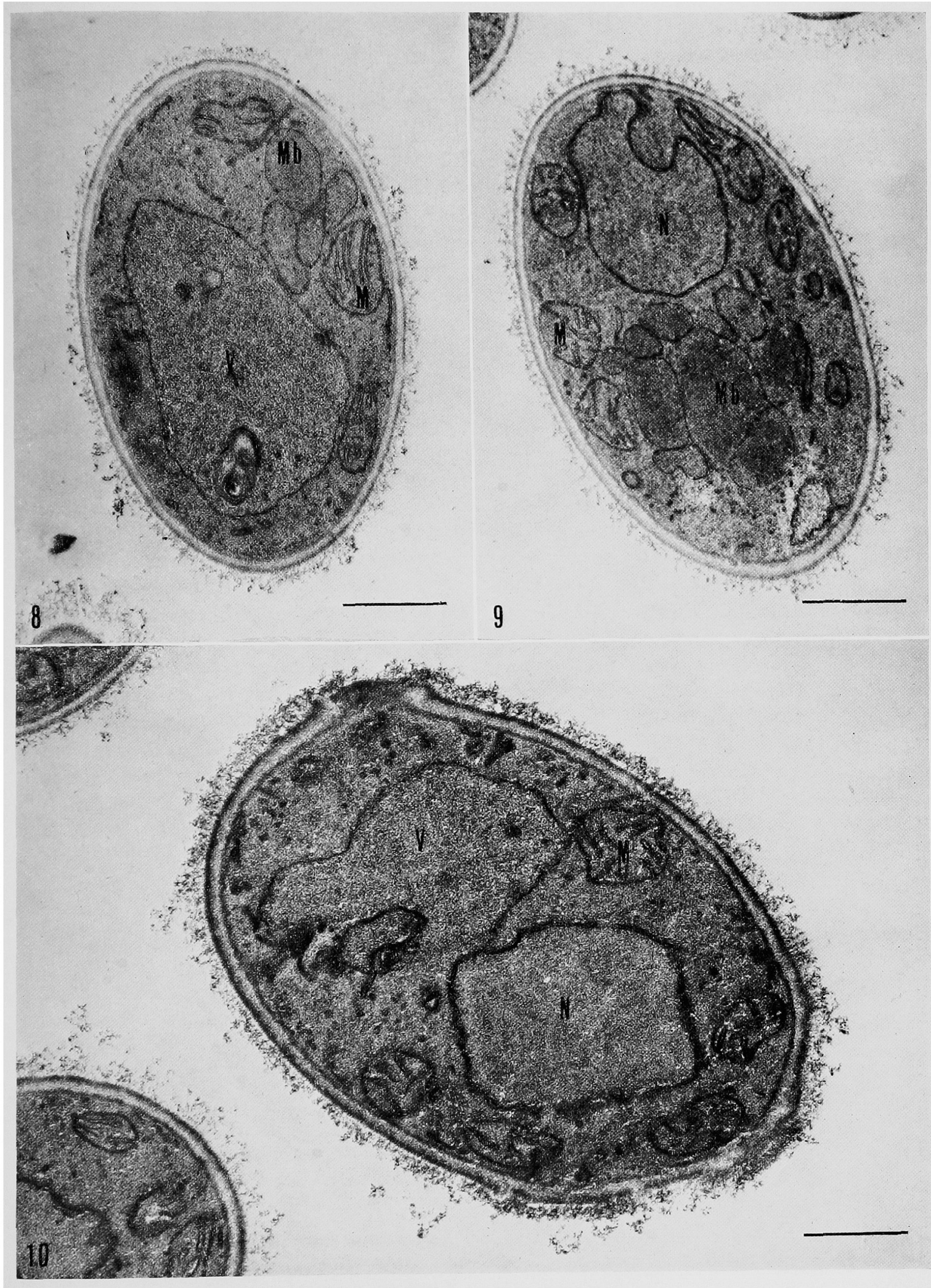




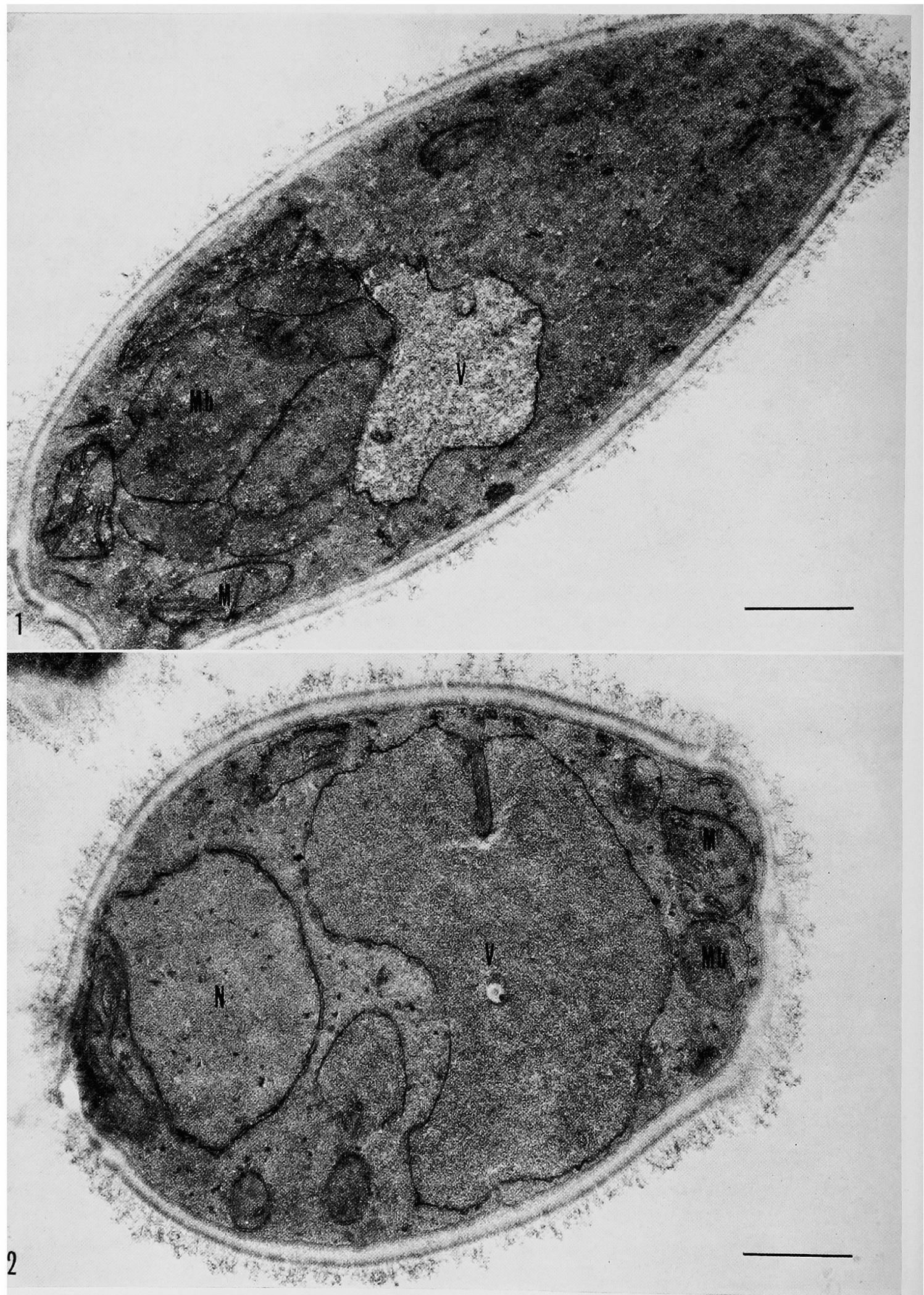


cells were transferred into a methanol-glucose medium, catalase activity in the cells still increased for a while, reached the maximum, and then decreased gradually to a certain low level (Fig. 6). However, the activity in $\mathrm{ml}$ broth was maintained at a constant high level during several hours of the cultivation (Fig. 6). In addition, the activity in the cells growing on glucose was maintained at a constant level throughout the cultivation. These results suggest that glucose would not stimulate the inactivation of catalase, but rather inhibit the enzyme synthesis.

Microbodies in the partially induced cells (Fig. 8) developed well when the cells were cultivated on methanol with or without cycloheximide (Figs. 9 and 11). Neither growth nor degradation of microbodies was observed in the cells incubated without any carbon source (Fig. 12). On the other hand, microbodies seemed to be degraded during the cultivation on methanol-glucose (Fig. 10). Electron microscopical observation revealed that the induction of catalase activity was closely related to the development of microbodies.

AT inhibited only $40 \%$ of the catalase activity in the cell homogenate (Table I). Low sensitivity to the inhibitor was also demonstrated with respect to the catalases of C. tropicalis $^{16)}$ and C. boidinii. ${ }^{18}$ The enzyme of methanol-grown $C$. boidinii was inhibited by $87.5 \%$ at the inhibitor concentration of $100 \mathrm{~mm}^{18)}$ and about $100 \%$ at $150 \mathrm{~mm}^{91}$

Acknowledgements. The authors are indebted to Prof. K. Ogata, Department of Agricultural Chemistry, Faculty of Agriculture, Kyoto University, for his generous gift of a strain of Kloeckera sp. No. 2201.

This work was supported partly by grants from the Ministry of Education, Japanese Government, and from the Asahi Glass Foundation for the Contribution to Industrial Technology.

\section{REFERENCES}

1) T. Fujii and K. Tonomura, Agr. Biol. Chem., 36, 2297 (1972).

2) H. Sahm and F. Wagner, Eur. J. Biochem., 36, 250 (1973).

3) N. Kato, Y. Tani and K. Ogata, Agr. Biol. Chem., 38, 675 (1974).

4) O. Volfová, Folia Microbiol., 20, 307 (1975).

5) S. Fukui, A. Tanaka, S. Kawamoto, S. Yasuhara, Y. Teranishi and M. Osumi, J. Bacteriol., 123, 317 (1975).

6) J. P. van Dijken, M. Veenhuis, N. J. W. Kregervan Rij and W. Harder, Arch. Microbiol., 102, 41 (1975).

7) H. Sahm, R. Roggenkamp, F. Wagner and W. Hinkelmann, J. Gen. Microbiol, 88, 218 (1975).

8) S. Fukui, S. Kawamoto, S. Yasuhara, A. Tanaka, M. Osumi and F. Imaizumi, Eur. J. Biochem., 59, 561 (1975).

9) R. Roggenkamp, H. Sahm and F. Wagner, FEBS Lett., 41, 283 (1974).

10) Y. Teranishi, S. Kawamoto, A. Tanaka, M. Osumi and S. Fukui, Agr. Biol. Chem.,, 38, 1221 (1974).

11) K. Ogata, H. Nishikawa, M. Ohsugi and T. Tochikura, J. Ferment. Technol., 48, 389 (1970).

12) M. Yamamura, Y. Teranishi, A. Tanaka and S. Fukui, Agr. Biol. Chem, 39, 13 (1975).

13) O. H. Lowry, N. J. Rosebrough, A. L. Farr and R. J. Randall, J. Biol. Chem., 193, 265 (1951).

14) T. E. Barman, "Enzyme Handbook," Vol. 1, Springer-Verlag, Berlin, 1969, p. 232.

15) M. J. Poznansky and T. M. Chang, Biochim. Biophys. Acta, 334, 103 (1974).

16) Y. Teranishi, A. Tanaka, M. Osumi and S. Fukui, Agr. Biol. Chem., 38, 1213 (1974).

17) E. Margoliash and A. Novogrodsky, Biochem. J., 68, 468 (1958).

18) J. Vořísék and O. Volfová, FEBS Lett., 52, 246 (1975).

19) M. Aboud and M. Burger, Biochem. Biophys. Res. Commun., 43, 174 (1971).

20) R. W. Butcher and E. W. Sutherland, J. Biol. Chem., 237, 1244 (1962).

21) H. P. Hoffmann, A. Szabo and C. J. Avers, $J$. Bacteriol., 104, 581 (1970).

22) R. W. Parish, Arch. Microbiol., 105, 187 (1975).

FIG. 11. Electron Micrograph of Cell Grown in a Methanol Medium Containing Cycloheximide. Partially induced cell was cultivated for $8 \mathrm{hr}$ in $2 \%$ methanol medium containing $2 \mathrm{mg} / \mathrm{ml}$ of cycloheximide. $\mathrm{Mb}$, microbody; $\mathrm{M}$, mitochondrion; $\mathrm{V}$, vacuole. Bar, $0.5 \mu \mathrm{m}$.

FIG. 12. Electron Micrograph of Cell Incubated without Carbon Source.

Partially induced cell was incubated for $8 \mathrm{hr}$ in a medium containing no carbon source: $\mathrm{Mb}$, microbody; $M$, mitochondrion; N, nucleus; V, vacuole. Bar, $0.5 \mu \mathrm{m}$. 
23) M. Osumi, N. Miwa, Y. Teranishi, A. Tanaka and S. Fukui, Arch. Microbiol., 99, 181 (1974).

24) R. Roggenkamp, H. Sahm, W. Hinkelmann and F. Wagner, Eur. J. Biochem., 59, 231 (1975).

25) J. P. van Dijken, M. Veenhuis, C. A. Vermeulen and W. Harder, Arch. Microbiol., 105, 261 (1975).

26) M. Osumi, F. Fukuzumi, Y. Teranishi, A. Tanaka and S. Fukui, Arch. Microbiol., 103, 1 (1975).

27) A. Tanaka, S. Yasuhara, S. Kawamoto, S. Fukui and M. Osumi, J. Bacteriol., 126, 919 (1976).

28) T. C. M. Seah and J. P. Kaplan, J. Biol. Chem., 248, 2889 (1973).

29) H. Dellweg, G. Schlonderer, F. Diel and W. Held, "Microbial Growth on $C_{1}$-Compounds," The Soc. Ferment. Technol., Japan, 1975, p. 149. 